\title{
Artificial Intelligence for the Prediction of Helicobacter Pylori Infection in Endoscopic Images: Systematic Review and Meta-Analysis Of Diagnostic Test Accuracy
}

\author{
Chang Seok Bang ${ }^{1,2,3,4}$, MD, PhD; Jae Jun Lee ${ }^{3,4,5}$, MD; Gwang Ho Baik ${ }^{1,2}$, MD \\ ${ }^{1}$ Department of Internal Medicine, Hallym University College of Medicine, Chuncheon, Republic of Korea \\ ${ }^{2}$ Institute for Liver and Digestive Diseases, Hallym University, Chuncheon, Republic of Korea \\ ${ }^{3}$ Institute of New Frontier Research, Hallym University College of Medicine, Chuncheon, Republic of Korea \\ ${ }^{4}$ Division of Big Data and Artificial Intelligence, Chuncheon Sacred Heart Hospital, Chuncheon, Republic of Korea \\ ${ }^{5}$ Department of Anesthesiology and Pain Medicine, Hallym University College of Medicine, Chuncheon, Republic of Korea
}

Corresponding Author:

Chang Seok Bang, MD, PhD

Department of Internal Medicine

Hallym University College of Medicine

Sakju-ro 77

Chuncheon,

Republic of Korea

Phone: 82332405000

Fax: 82332418064

Email: csbang@hallym.ac.kr

\section{Abstract}

Background: Helicobacter pylori plays a central role in the development of gastric cancer, and prediction of $H$ pylori infection by visual inspection of the gastric mucosa is an important function of endoscopy. However, there are currently no established methods of optical diagnosis of $H$ pylori infection using endoscopic images. Definitive diagnosis requires endoscopic biopsy. Artificial intelligence (AI) has been increasingly adopted in clinical practice, especially for image recognition and classification.

Objective: This study aimed to evaluate the diagnostic test accuracy of AI for the prediction of $H$ pylori infection using endoscopic images.

Methods: Two independent evaluators searched core databases. The inclusion criteria included studies with endoscopic images of $H$ pylori infection and with application of AI for the prediction of $H$ pylori infection presenting diagnostic performance. Systematic review and diagnostic test accuracy meta-analysis were performed.

Results: Ultimately, 8 studies were identified. Pooled sensitivity, specificity, diagnostic odds ratio, and area under the curve of AI for the prediction of $H$ pylori infection were 0.87 (95\% CI 0.72-0.94), 0.86 (95\% CI 0.77-0.92), 40 (95\% CI 15-112), and 0.92 (95\% CI 0.90-0.94), respectively, in the 1719 patients (385 patients with $H$ pylori infection vs 1334 controls). Meta-regression showed methodological quality and included the number of patients in each study for the purpose of heterogeneity. There was no evidence of publication bias. The accuracy of the AI algorithm reached $82 \%$ for discrimination between noninfected images and posteradication images.

Conclusions: An AI algorithm is a reliable tool for endoscopic diagnosis of $H$ pylori infection. The limitations of lacking external validation performance and being conducted only in Asia should be overcome.

Trial Registration: PROSPERO CRD42020175957; https://www.crd.york.ac.uk/prospero/display_record.php?RecordID=175957

(J Med Internet Res 2020;22(9):e21983) doi: 10.2196/21983

\section{KEYWORDS}

artificial intelligence; convolutional neural network; deep learning; machine learning; endoscopy; Helicobacter pylori 


\section{Introduction}

More than half of the world's population is infected with the Helicobacter pylori bacteria [1], which is associated with various disorders, such as gastritis, peptic ulcer, mucosa-associated lymphoid tissue lymphoma, gastric adenocarcinoma, and immune thrombocytopenic purpura [2,3]. The infection causes chronic atrophic gastritis, intestinal metaplasia, dysplasia, and gastric cancer in sequence [4]. The International Agency for Research on Cancer has categorized $H$ pylori as a group 1 carcinogen [5]. Elimination of this pathogen is considered the most promising strategy for the prevention of gastric cancer [6,7].

An important aspect of endoscopy is the ability to predict $H$ pylori-induced gastritis by visual inspection of the gastric mucosa to identify patients at high risk for gastric cancer. Representative features of $H$ pylori-induced gastritis have been reported in the literature, including mucosal edema, atrophy, diffuse erythema, enlargement of mucosal folds, or mucosal nodularity [8,9]. The regular arrangement of collecting venules and fundic gland polyps has been suggested as a predictive marker of the $H$ pylori-naïve stomach. Also, map-like redness under white-light imaging (WLI) or a cracked pattern under blue-laser imaging (BLI) have been suggested as features of a posteradicated gastric mucosa $[8,9]$.

These endoscopic features do not have objective indicators, and there is the potential for interobserver or intraobserver variability in the optical diagnosis of $H$ pylori-infected mucosa [10]. Although expert endoscopists might reliably identify an $\mathrm{H}$ pylori infection with meticulous visual inspection of the mucosa during endoscopic examination, novice endoscopists require substantial time to perform this task efficiently. Image-enhanced endoscopy (IEE), such as narrow-band imaging (NBI), BLI, or linked color imaging (LCI), with or without magnification, has been developed. Previous studies have indicated increased diagnostic accuracy of gastrointestinal neoplasms with the application of these modalities during endoscopic examination [11,12]. This also requires considerable training and prolonged procedure time. There are no uniform features of $H$ pylori infection in IEE [12]. Therefore, there are currently no established methods of optical endoscopic diagnosis of $H$ pylori infection. Definitive diagnosis continues to require endoscopic biopsy, which is categorized as an invasive diagnostic test.

Artificial intelligence (AI) has been increasingly adopted in clinical practice, especially for image recognition and classification [13]. This technique has shown promising diagnostic performance using endoscopic images, such as detecting cancer or neoplastic lesions and classifying neoplastic or nonneoplastic lesions in the gastrointestinal tract [14]. Application of AI in endoscopic examination is expected to be useful. It can help detect $H$ pylori infection in real time and determine the optimum definitive test for $H$ pylori infection. There has been no diagnostic test accuracy meta-analysis of AI for the prediction of $H$ pylori infection using endoscopic images.

This study aimed to evaluate the diagnostic performance of AI for the diagnosis of $\mathrm{H}$ pylori infection using endoscopic images.

\section{Methods}

\section{Ethics}

This study adhered to the guidelines of the Preferred Reporting Items for a Systematic Review and Meta-analysis of Diagnostic Test Accuracy Studies (PRISMA-DTA) [15]. The protocol of this study was registered at the International Prospective Register of Systematic Reviews (PROSPERO) [CRD42020175957] on March 2019 before initiating the study. Approval of the institutional review board was exempted as only anonymized data was collected from the literature.

\section{Literature Searching Strategy}

Two independent evaluators (CSB and JJL) having published 23 systematic reviews and 11 PROSPERO protocols searched PubMed, Embase, and the Cochrane Library using common keywords relevant to $H$ pylori infection and AI (inception to March 2020). The abstracts of all identified studies were reviewed to exclude irrelevant articles. Full-text reviews were conducted to determine whether the inclusion criteria were satisfied in all the studies. Bibliographies were also reviewed to identify additional relevant articles. Disagreements between the evaluators were resolved by consultation with a third evaluator (GHB). The details are presented in Multimedia Appendix 1.

\section{Selection Criteria}

We included studies that met the following criteria: (1) studies with endoscopic images of $H$ pylori infection as a case group and endoscopic images without $H$ pylori infection as a negative control group; (2) application of the AI algorithm for the prediction of $H$ pylori infection; (3) inclusion of diagnostic performance indices of the AI algorithm, including sensitivity, specificity, positive predictive value (PPV), negative predictive value (NPV), positive likelihood ratio (PLR), negative likelihood ratio (NLR), diagnostic odds ratio (DOR), or accuracy, which enable an estimation of true positive (TP), false positive (FP), false negative $(\mathrm{FN})$, and true negative $(\mathrm{TN})$ values for the prediction of $H$ pylori infection using endoscopic images; (4) prospective or retrospective study design; (5) human adult subjects; and (6) full-text publications written in English. The exclusion criteria included (1) narrative reviews; (2) letters, comments, editorials, or protocol studies; (3) guidelines; and (4) systematic reviews and meta-analyses. Studies meeting at least one of the exclusion criteria were excluded from the analysis.

\section{Methodological Quality}

The Quality Assessment of Diagnostic Accuracy Studies-2 (QUADAS-2) tool was used to determine the methodological quality of the included articles. This tool contains 4 domains: patient selection, index test, reference standard, and flow and timing [16]. Each domain was assessed in terms of high, low, or unclear risk of bias, and the first 3 domains were also assessed in terms of high, low, or unclear concerns regarding applicability [16]. Review Manager version 5.3.3 (RevMan for Windows 7, Nordic Cochrane Centre) was used to generate the summary figure of the methodological quality evaluation. Data extraction, 
primary and modifier-based analyses, and statistical analysis are described in Multimedia Appendix 2 [17-20].

\section{Results}

\section{Identification of Relevant Studies}

In total, 161 articles were identified by searching 3 electronic databases. Among them, 59 were duplicate studies, and 75 were excluded during the initial screening by reviewing titles and abstracts. Full texts of the remaining 27 articles were thoroughly reviewed. Among these, 19 studies were excluded from the final analysis due to the following reasons: narrative review $(n=4)$, incomplete data $(\mathrm{n}=14)$, and systematic review or meta-analysis $(n=1$; the topic of this systematic review was the role of nonmagnified endoscopy for the assessment of $H$ pylori infection) [8]. The remaining 8 studies [9,10,21-26] were included in the final analysis. Figure 1 illustrates a flow diagram showing the process used to identify the relevant articles.

Figure 1. Flow diagram of the identification of relevant studies.

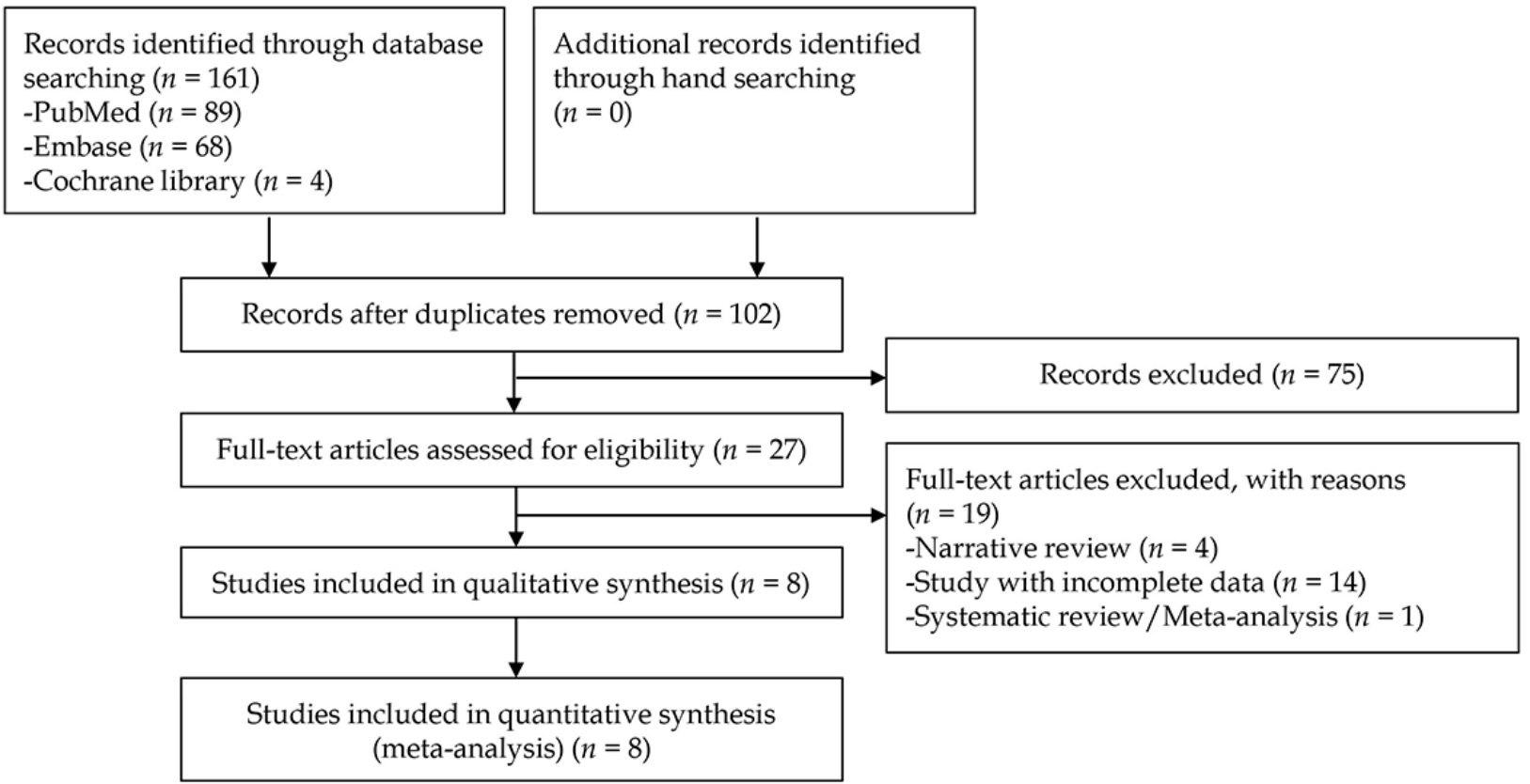

\section{Characteristics of the Included Studies}

The included studies could be categorized by analysis based on the number of enrolled patients $[9,10,22,23,25,26]$ and number of enrolled images $[9,10,21,24]$. Two studies $[9,10]$ presented both patient-based and image-based analyses. Enrolled studies presented performance of the AI algorithm with test dataset (internal validation), and there was no study that presented external validation performance.

Among the 8 studies [9,10,21-26] included for the prediction of $H$ pylori infection using endoscopic images, we identified 1719 patients (385 patients with $H$ pylori infection vs 1334 controls). Additionally, 2855 endoscopic images with $H$ pylori infection and 2287 control images including 514 posteradicated images were identified.

Among the studies, 5 were retrospectively conducted $[9,10,21,22,25]$, and $3[23,24,26]$ were prospectively conducted.
All studies were conducted in Asia, and the age of the enrolled population ranged from a mean of 48.6 years to a median of 64 years. Most studies [9,21-24,26] established the AI algorithm based on the convolutional neural network (CNN), whereas 2 studies [10,25] established support vector machine (SVM)-based algorithms. Most studies [9,21,22,24-26] used endoscopic images with WLI, whereas a study by Yasuda et al [10] used endoscopic images with LCI, and Nakashima et al [23] used LCI and BLI images in addition to endoscopic images with WLI. While most studies [9,10,21,22,24-26] presented the performance of the AI algorithm as a single primary outcome, one study [23] also presented a feature map, which implies visualizing where established $\mathrm{AI}$ algorithms pay attention to and indicate a region of interest.

These characteristics (modifiers) were evaluated as potential sources of heterogeneity through the subgroup analysis and meta-regression. Detailed characteristics of the studies are presented in Table 1. 
Table 1. Clinical characteristics of the included studies.

\begin{tabular}{|c|c|c|c|c|c|c|c|c|c|c|}
\hline $\begin{array}{l}\text { Study, } \\
\text { format, } \\
\text { nationali- } \\
\text { ty }\end{array}$ & $\begin{array}{l}\text { Type of } \\
\mathrm{AI}^{\mathrm{a}}\end{array}$ & $\begin{array}{l}\text { Type of endoscopy, } \\
\text { diagnostic method of } \\
\text { Helicobacter pylori } \\
\text { infection }\end{array}$ & $\begin{array}{l}\text { Number of } \\
\text { cases in test } \\
\text { dataset }\end{array}$ & $\begin{array}{l}\text { Number of } \\
\text { controls in test } \\
\text { dataset }\end{array}$ & $\begin{array}{l}\text { Age of patients in test } \\
\text { dataset; gender in pa- } \\
\text { tients in test dataset } \\
\left(\mathrm{M} / \mathrm{F}^{\mathrm{b}}\right)\end{array}$ & $\mathrm{TP}^{\mathrm{c}}$ & $\mathrm{FP}^{\mathrm{d}}$ & $\mathrm{FN}^{\mathrm{e}}$ & $\mathrm{TN}^{\mathrm{f}}$ & $\begin{array}{l}\text { Unit of analy- } \\
\text { sis }\end{array}$ \\
\hline $\begin{array}{l}\text { Yasuda et } \\
\text { al [10], } \\
\text { retrospec- } \\
\text { tive, } \\
\text { Japan }\end{array}$ & $\begin{array}{l}\text { Support } \\
\text { vector } \\
\text { machine }\end{array}$ & $\begin{array}{l}\mathrm{LCI}^{\mathrm{g}} \text {; more than } 2 \\
\text { different tests in } \\
\text { each case (histology, } \\
\text { serum antibody, } \\
\text { stool antigen, urea } \\
\text { breath test) }\end{array}$ & $\begin{array}{l}42 \mathrm{H} \text { pylori } \\
\text { patients }\end{array}$ & $\begin{array}{l}63 \text { controls } \\
\text { ( } 46 \text { posteradi- } \\
\text { cation patients } \\
\text { and } 17 \text { unin- } \\
\text { fected pa- } \\
\text { tients) }\end{array}$ & $\begin{array}{l}\text { Median } 64 \text { years } \\
\text { (range 26-88); (61/44) }\end{array}$ & 38 & 9 & 4 & 54 & $\begin{array}{l}\text { Patient- } \\
\text { based }\end{array}$ \\
\hline - & - & - & $\begin{array}{l}210 H \text { py- } \\
\text { lori-positive } \\
\text { images }\end{array}$ & $\begin{array}{l}315 \text { control } \\
\text { images ( } 230 \\
\text { posteradica- } \\
\text { tion and } 85 \\
\text { uninfected im- } \\
\text { ages) }\end{array}$ & - & 161 & 70 & 49 & 245 & Image-based \\
\hline - & - & - & $\begin{array}{l}210 H \text { py- } \\
\text { lori-positive } \\
\text { images }\end{array}$ & $\begin{array}{l}85 \text { uninfected } \\
\text { images }(H p y \text { - } \\
\text { lori-naïve) }\end{array}$ & - & 161 & 9 & 49 & 76 & $\begin{array}{l}\text { Image-based } \\
\text { (infected vs } \\
\text { uninfected) }\end{array}$ \\
\hline - & - & - & $\begin{array}{l}210 H \text { py- } \\
\text { lori-positive } \\
\text { images }\end{array}$ & $\begin{array}{l}230 \text { posteradi- } \\
\text { cation images }\end{array}$ & - & 161 & 61 & 49 & 169 & $\begin{array}{l}\text { Image-based } \\
\text { (infected vs } \\
\text { after-eradica- } \\
\text { tion) }\end{array}$ \\
\hline - & - & - & $\begin{array}{l}85 \text { uninfect- } \\
\text { ed images }\end{array}$ & $\begin{array}{l}230 \text { posteradi- } \\
\text { cation images }\end{array}$ & - & 76 & 61 & 9 & 169 & $\begin{array}{l}\text { Image-based } \\
\text { (uninfected } \\
\text { vs after-erad- } \\
\text { ication) }\end{array}$ \\
\hline $\begin{array}{l}\text { Zheng et } \\
\text { al [21], } \\
\text { retrospec- } \\
\text { tive, Chi- } \\
\text { na }\end{array}$ & $\mathrm{CNN}^{\mathrm{h}}$ & $\begin{array}{l}\text { WLI' }{ }^{\mathrm{i}} \text { histology with } \\
\text { immunohistochem- } \\
\text { istry (if negative, } \\
\text { urea breath test was } \\
\text { done) }\end{array}$ & $\begin{array}{l}2575 \text { H py- } \\
\text { lori-positive } \\
\text { images }\end{array}$ & $\begin{array}{l}1180 \text { control } \\
\text { images } \\
\text { (whether } \\
\text { posteradica- } \\
\text { tion or unin- } \\
\text { fected images } \\
\text { is unknown) }\end{array}$ & $\begin{array}{l}\text { Mean } 48.6 \text { years (SD } \\
12.9) ;(220 / 232)\end{array}$ & 2359 & 17 & 216 & 1163 & Image-based \\
\hline $\begin{array}{l}\text { Shichijo } \\
\text { et al [9], } \\
\text { retrospec- } \\
\text { tive, } \\
\text { Japan }\end{array}$ & $\mathrm{CNN}$ & $\begin{array}{l}\text { WLI; serum or urine } \\
\text { antibody, stool anti- } \\
\text { gen, urea breath test }\end{array}$ & $\begin{array}{l}70 \mathrm{H} \mathrm{py-} \\
\text { lori-positive } \\
\text { patients }\end{array}$ & $\begin{array}{l}777 \text { controls } \\
\text { ( } 284 \text { posteradi- } \\
\text { cation and } 493 \\
\text { uninfected im- } \\
\text { ages) }\end{array}$ & - & 44 & 47 & 26 & 730 & $\begin{array}{l}\text { Patient- } \\
\text { based }\end{array}$ \\
\hline - & - & - & $\begin{array}{l}59 \text { H py- } \\
\text { lori-positive } \\
\text { images }\end{array}$ & $\begin{array}{l}477 \text { uninfect- } \\
\text { ed images }(H \\
\text { pylori-naïve) }\end{array}$ & - & 44 & 12 & 15 & 465 & $\begin{array}{l}\text { Image-based } \\
\text { (infected vs } \\
\text { uninfected) }\end{array}$ \\
\hline - & - & - & $\begin{array}{l}55 H \text { py- } \\
\text { lori-positive } \\
\text { images }\end{array}$ & $\begin{array}{l}182 \text { posteradi- } \\
\text { cation images }\end{array}$ & - & 44 & 35 & 11 & 147 & $\begin{array}{l}\text { Image-based } \\
\text { (infected vs } \\
\text { after-eradica- } \\
\text { tion) }\end{array}$ \\
\hline - & - & - & $\begin{array}{l}481 \text { uninfect- } \\
\text { ed images }\end{array}$ & $\begin{array}{l}249 \text { posteradi- } \\
\text { cation images }\end{array}$ & - & 465 & 102 & 16 & 147 & $\begin{array}{l}\text { Image-based } \\
\text { (uninfected } \\
\text { vs after-erad- } \\
\text { ication) }\end{array}$ \\
\hline $\begin{array}{l}\text { Nakashima } \\
\text { et al [23], } \\
\text { prospec- } \\
\text { tive, } \\
\text { Japan }\end{array}$ & $\mathrm{CNN}$ & $\begin{array}{l}\text { WLI; serum anti- } \\
\text { body (H pylori IgG } \\
\geq 10 \mathrm{U} / \mathrm{mL} \text { was con- } \\
\text { sidered positive) }\end{array}$ & $\begin{array}{l}30 \text { H pylori } \\
\text { patients }\end{array}$ & $\begin{array}{l}30 \text { controls } \\
\text { (uninfected } \\
\text { patients; } H \text { py- } \\
\text { lori-naïve) }\end{array}$ & - & 20 & 12 & 10 & 18 & $\begin{array}{l}\text { Patient- } \\
\text { based }\end{array}$ \\
\hline - & - & LCI & - & - & - & 29 & 1 & 1 & 29 & $\begin{array}{l}\text { Patient- } \\
\text { based }\end{array}$ \\
\hline - & - & $\mathrm{BLI}^{\mathrm{j}}$-bright & - & - & - & 29 & 4 & 1 & 26 & $\begin{array}{l}\text { Patient- } \\
\text { based }\end{array}$ \\
\hline
\end{tabular}




\begin{tabular}{|c|c|c|c|c|c|c|c|c|c|c|}
\hline $\begin{array}{l}\text { Study, } \\
\text { format, } \\
\text { nationali- } \\
\text { ty }\end{array}$ & $\begin{array}{l}\text { Type of } \\
\mathrm{AI}^{\mathrm{a}}\end{array}$ & $\begin{array}{l}\text { Type of endoscopy, } \\
\text { diagnostic method of } \\
\text { Helicobacter pylori } \\
\text { infection }\end{array}$ & $\begin{array}{l}\text { Number of } \\
\text { cases in test } \\
\text { dataset }\end{array}$ & $\begin{array}{l}\text { Number of } \\
\text { controls in test } \\
\text { dataset }\end{array}$ & $\begin{array}{l}\text { Age of patients in test } \\
\text { dataset; gender in pa- } \\
\text { tients in test dataset } \\
\left(\mathrm{M} / \mathrm{F}^{\mathrm{b}}\right)\end{array}$ & $\mathrm{TP}^{\mathrm{c}}$ & $\mathrm{FP}^{\mathrm{d}}$ & $\mathrm{FN}^{\mathrm{e}}$ & $\mathrm{TN}^{\mathrm{f}}$ & $\begin{array}{l}\text { Unit of analy- } \\
\text { sis }\end{array}$ \\
\hline $\begin{array}{l}\text { Itoh et al } \\
{[24],} \\
\text { prospec- } \\
\text { tive, } \\
\text { Japan }\end{array}$ & $\mathrm{CNN}$ & $\begin{array}{l}\text { WLI; serum anti- } \\
\text { body (H pylori IgG } \\
\geq 10 \mathrm{U} / \mathrm{mL} \text { was con- } \\
\text { sidered positive) }\end{array}$ & $\begin{array}{l}15 \mathrm{H} \mathrm{py} \text { - } \\
\text { lori-positive } \\
\text { images }\end{array}$ & $\begin{array}{l}15 \text { control im- } \\
\text { ages (uninfect- } \\
\text { ed patients; } H \\
\text { pylori-naïve) }\end{array}$ & - & 13 & 2 & 2 & 13 & Image-based \\
\hline $\begin{array}{l}\text { Shichijo } \\
\text { et al [22], } \\
\text { retrospec- } \\
\text { tive, } \\
\text { Japan }\end{array}$ & $\mathrm{CNN}$ & $\begin{array}{l}\text { WLI; serum or urine } \\
\text { antibody, stool anti- } \\
\text { gen, urea breath test }\end{array}$ & $\begin{array}{l}72 \text { H pylori } \\
\text { patients }\end{array}$ & $\begin{array}{l}325 \text { controls } \\
\text { (uninfected } \\
\text { patients; } H \text { py- } \\
\text { lori-naïve) }\end{array}$ & $\begin{array}{l}\text { mean } 50.4(\mathrm{SD} 11.2) \text {, } \\
(168 / 226)\end{array}$ & 64 & 41 & 8 & 284 & $\begin{array}{l}\text { Patient- } \\
\text { based }\end{array}$ \\
\hline $\begin{array}{l}\text { Huang et } \\
\text { al [25], } \\
\text { retrospec- } \\
\text { tive, Tai- } \\
\text { wan }\end{array}$ & $\begin{array}{l}\text { Sequen- } \\
\text { tial for- } \\
\text { ward } \\
\text { floating } \\
\text { selection } \\
\text { with } \\
\text { SVM }^{k}\end{array}$ & $\begin{array}{l}\text { WLI; histology ( } 3 \\
\text { pairs of samples } \\
\text { from the topographic } \\
\text { sites, including } \\
\text { antrum, body, and } \\
\text { cardia were obtained } \\
\text { in a uniform way) }\end{array}$ & $\begin{array}{l}130 \text { H pylori } \\
\text { patients }\end{array}$ & $\begin{array}{l}106 \text { controls } \\
\text { (whether } \\
\text { posteradica- } \\
\text { tion or unin- } \\
\text { fected patients } \\
\text { is unknown) }\end{array}$ & - & 128 & 21 & 2 & 85 & $\begin{array}{l}\text { Patient- } \\
\text { based }\end{array}$ \\
\hline $\begin{array}{l}\text { Huang et } \\
\text { al [26], } \\
\text { prospec- } \\
\text { tive, Tai- } \\
\text { wan }\end{array}$ & $\begin{array}{l}\text { Refined } \\
\text { feature se- } \\
\text { lection } \\
\text { with neu- } \\
\text { ral net- } \\
\text { work }\end{array}$ & $\begin{array}{l}\text { WLI; histology ( } 3 \\
\text { pairs of samples } \\
\text { from the topographic } \\
\text { sites, including } \\
\text { antrum, body, and } \\
\text { cardia were obtained } \\
\text { in a uniform way) }\end{array}$ & $\begin{array}{l}41 \text { H pylori } \\
\text { patients }\end{array}$ & $\begin{array}{l}33 \text { controls } \\
\text { (whether } \\
\text { posteradica- } \\
\text { tion or unin- } \\
\text { fected patients } \\
\text { is unknown) }\end{array}$ & - & 35 & 3 & 6 & 30 & $\begin{array}{l}\text { Patient- } \\
\text { based }\end{array}$ \\
\hline
\end{tabular}

\footnotetext{
${ }^{\mathrm{a}} \mathrm{AI}$ : artificial intelligence.

${ }^{\mathrm{b}} \mathrm{M} / \mathrm{F}$ : make/female.

${ }^{\mathrm{c}} \mathrm{TP}$ : true positive.

${ }^{\mathrm{d}} \mathrm{FP}$ : false positive.

${ }^{\mathrm{e}} \mathrm{FN}$ : false negative.

$\mathrm{f}_{\mathrm{TN}}$ : true negative.

$\mathrm{g}_{\text {LCI: linked color imaging. }}$

${ }^{\mathrm{h}} \mathrm{CNN}$ : convolutional neural network.

${ }^{\mathrm{i}}$ WLI: white-light imaging.

${ }^{\mathrm{j}} \mathrm{BLI}$ : blue-laser imaging.

${ }_{\mathrm{k}} \mathrm{SVM}$ : support vector machine.
}

\section{Methodological Quality of the Studies}

Among the 8 studies $[9,10,21-26]$ in the final analysis, 6 studies $[9,10,21,22,25,26]$ showed low risk of bias, and 2 studies $[23,24]$ showed high risk of bias in patient selection.

In terms of the patient selection, 4 studies [9,10,21,22] used multiple tests, including a biopsy, serology (serum anti-H pylori IgG titer), stool antigen test, urine examination (urine anti- $H$ pylori IgG titer), or a urea breath test for the determination of H pylori infection. Two studies [25,26] used only gastric biopsy; however, 3 pairs of samples from the topographic sites, including the antrum, body, and cardia were obtained in a uniform way. The remaining 2 studies [23,24] used only serology (serum anti-H pylori IgG titer) for the determination of $H$ pylori infection. Although a serology test is convenient and widely used in Japan, local validation is essential to determine the best cutoff values. A recent Cochrane review suggested that serology is less accurate for the diagnosis of $H$ pylori infection compared with the urea breath test [27].

For concerns regarding image selection, most studies $[9,10,21,22,25,26]$ did not limit the specific topographic area of the endoscopic still images for enrollment in the study. However, 2 studies $[23,24]$ used still images limited to the lesser curvature of the stomach. Considering that topographic distribution and density of $\mathrm{H}$ pylori is different according to the stage of gastritis, the results of these studies may include a risk of bias.

Considering the commonly detected pitfalls in patient and image selection described above, these 2 studies [23,24] were rated as high risk in the patient selection domain in the risk of bias evaluation.

Overall, studies $[23,24]$ with high risk in at least 1 of the 7 domains were rated as low methodological quality in the subgroup analysis (Figure 2). 
Figure 2. Quality Assessment of Diagnostic Accuracy Studies -2 for the assessment of the methodological qualities of all the enrolled studies. (+) denotes low risk of bias, (?) denotes unclear risk of bias, (-) denotes high risk of bias.

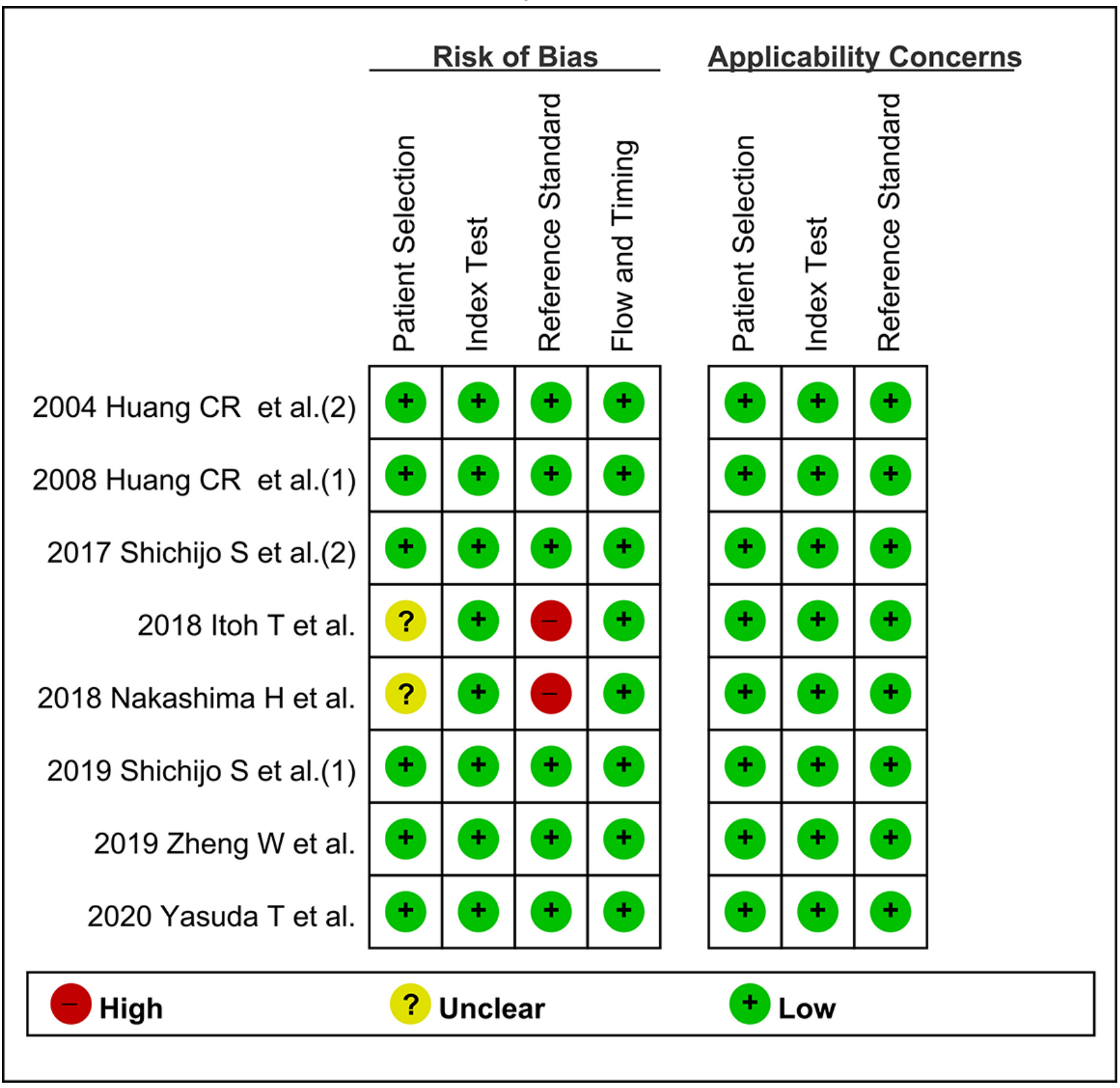

\section{Diagnostic Test Accuracy of Artificial Intelligence for the Prediction of Helicobacter pylori Infection}

Among the 6 studies $[9,10,22,23,25,26]$ of patient-based analysis, the sensitivity, specificity, PLR, NLR, DOR, and area under the curve (AUC) with $95 \% \mathrm{CI}$ of AI for the prediction of H pylori infection were 0.87 (95\% CI $0.72-0.94), 0.86(95 \% \mathrm{CI}$ 0.77-0.92), 6.2 (95\% CI 3.8-10.1), 0.15 (95\% CI 0.07-0.34), 40 (95\% CI 15-112), and 0.92 (95\% CI 0.90-0.94), respectively
(Table 2, Figure 3). The SROC curve, with a 95\% confidence region and prediction region, is illustrated in Figure 4. To investigate the clinical utility of AI, a Fagan nomogram was generated. Assuming 50\% prevalence of $H$ pylori infection, the Fagan nomogram shows that the posterior probability of $H$ pylori infection was $86 \%$ if the test was positive, and the posterior probability of absence of $H$ pylori infection was $13 \%$ if the test was negative (Figure 5). 
Table 2. Summary of diagnostic test accuracy and subgroup analysis of the included studies with patient-based analysis.

\begin{tabular}{|c|c|c|c|c|c|c|c|}
\hline Subgroup & $\begin{array}{l}\text { Number } \\
\text { of includ- } \\
\text { ed studies }\end{array}$ & $\begin{array}{l}\text { Sensitivity } \\
(95 \% \mathrm{CI})\end{array}$ & $\begin{array}{l}\text { Specificity } \\
(95 \% \mathrm{CI})\end{array}$ & $\mathrm{PLR}^{\mathrm{a}}$ & $\mathrm{NLR}^{\mathrm{b}}$ & $\mathrm{DOR}^{\mathrm{c}}$ & $\mathrm{AUC}^{\mathrm{d}}$ \\
\hline \multicolumn{8}{|l|}{$\begin{array}{l}\text { Methodological quality } \\
\text { of included studies }\end{array}$} \\
\hline High quality & 5 & $0.89(0.75-0.96)$ & $0.88(0.83-0.92)$ & $\begin{array}{l}7.7(5.6- \\
10.6)\end{array}$ & $0.12(0.05-0.28)$ & $64(32-129)$ & $0.94(0.91-0.95)$ \\
\hline Low quality & 1 & Null & Null & Null & Null & Null & Null \\
\hline \multicolumn{8}{|l|}{$\begin{array}{l}\text { Total number of includ- } \\
\text { ed patients }\end{array}$} \\
\hline$<100$ & 2 & Null & Null & Null & Null & Null & Null \\
\hline \multicolumn{8}{|l|}{ Format of study } \\
\hline Retrospective & 4 & $0.90(0.73-0.97)$ & $0.88(0.81-0.93)$ & $\begin{array}{l}7.6(5.3- \\
10.9)\end{array}$ & $0.11(0.04-0.32)$ & $68(29-158)$ & $0.94(0.91-0.95)$ \\
\hline Prospective & 2 & Null & Null & Null & Null & Null & Null \\
\hline \multicolumn{8}{|l|}{ Published year } \\
\hline After 2010 & 4 & $0.80(0.64-0.90)$ & $0.86(0.73-0.93)$ & $\begin{array}{l}5.6(2.8- \\
11.3)\end{array}$ & $0.24(0.13-0.45)$ & $23(8-72)$ & $0.90(0.87-0.92)$ \\
\hline Before 2010 & 2 & Null & Null & Null & Null & Null & Null \\
\hline \multicolumn{8}{|l|}{ Type of AI $\mathbf{f}^{\mathbf{f}}$} \\
\hline SVM $^{\mathrm{g}}$-based & 2 & Null & Null & Null & Null & Null & Null \\
\hline \multicolumn{8}{|l|}{$\begin{array}{l}\text { Type of endoscopic im- } \\
\text { age }\end{array}$} \\
\hline $\mathrm{WLI}^{\mathrm{h}}$ & 5 & $0.86(0.67-0.95)$ & $0.86(0.75-0.92)$ & $\begin{array}{l}6.1(3.4- \\
10.9)\end{array}$ & $0.16(0.06-0.42)$ & $37(11-124)$ & $0.92(0.89-0.94)$ \\
\hline $\mathrm{LCI}^{\mathrm{i}}$ & 1 & Null & Null & Null & Null & Null & Null \\
\hline $\begin{array}{l}\text { Classifying performance } \\
\text { between Helicobacter } \\
\text { pylori-positive vs } H \text { py- } \\
\text { lori-naïve patients }\end{array}$ & 2 & $0.82(0.74-0.89)$ & $0.85(0.81-0.89)$ & $\begin{array}{l}3.5(0.8- \\
14.3)\end{array}$ & $0.27(0.05-1.41)$ & $13(0.8-229)$ & Null \\
\hline
\end{tabular}

a PLR: positive likelihood ratio.

${ }^{\mathrm{b}} \mathrm{NLR}$ : negative likelihood ratio.

${ }^{\mathrm{c} D O R}$ : diagnostic odds ratio.

d AUC: area under the curve.

${ }^{\mathrm{e}}$ These modifiers were significant in the meta-regression analysis.

${ }_{\mathrm{AI}}$ : artificial intelligence.

$\mathbf{g}_{\text {SVM: support vector machine. }}$

${ }^{\mathbf{h}}$ WLI: white-light imaging.

i $_{\text {LCI: linked color imaging. }}$ 
Figure 3. Forest plots of sensitivity and specificity of artificial intelligence algorithm for the prediction of Helicobacter pylori infection in endoscopic images.

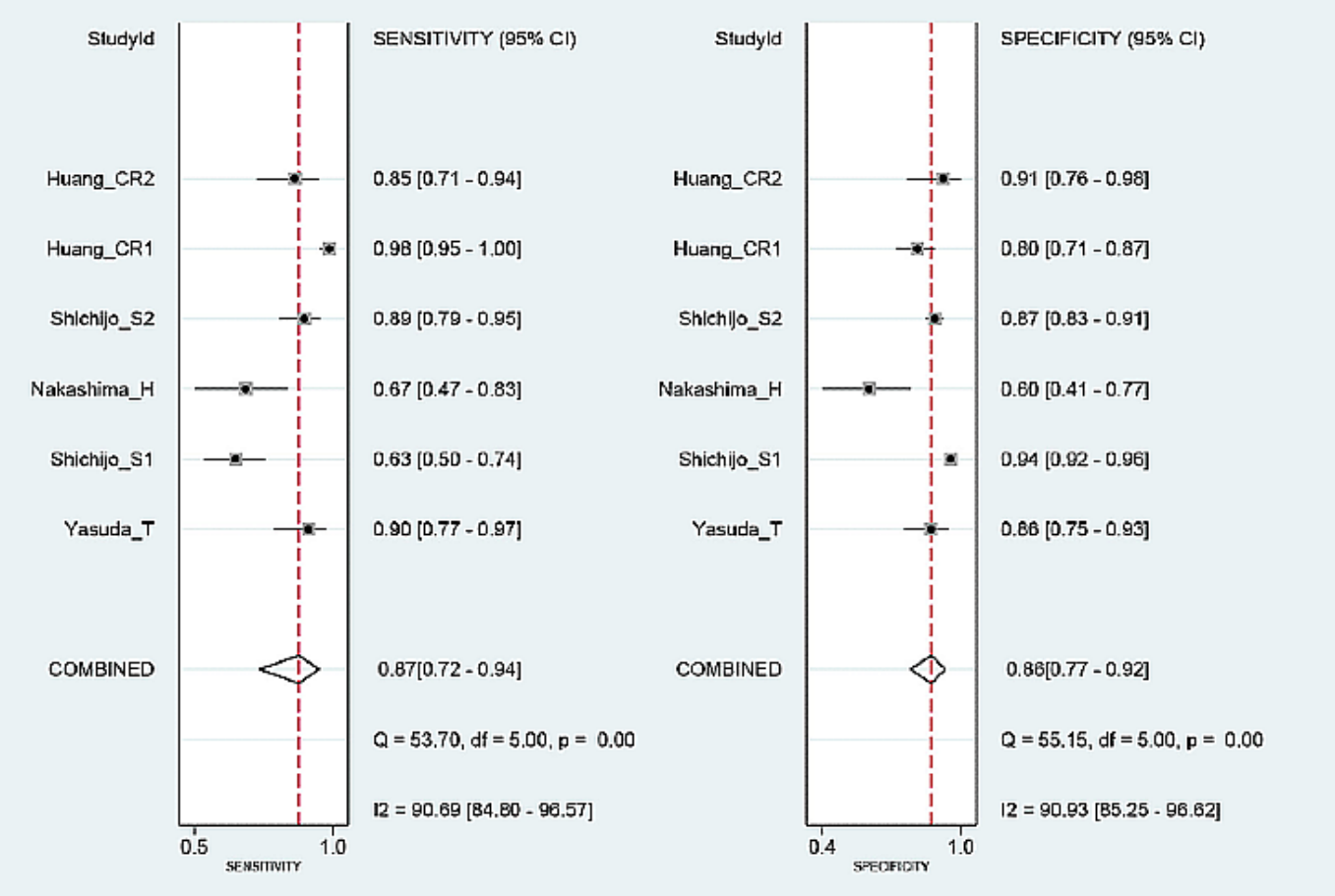

Figure 4. Summary receiver operating characteristic curve with $95 \%$ confidence region and prediction region for the prediction of Helicobacter pylori infection in endoscopic images.

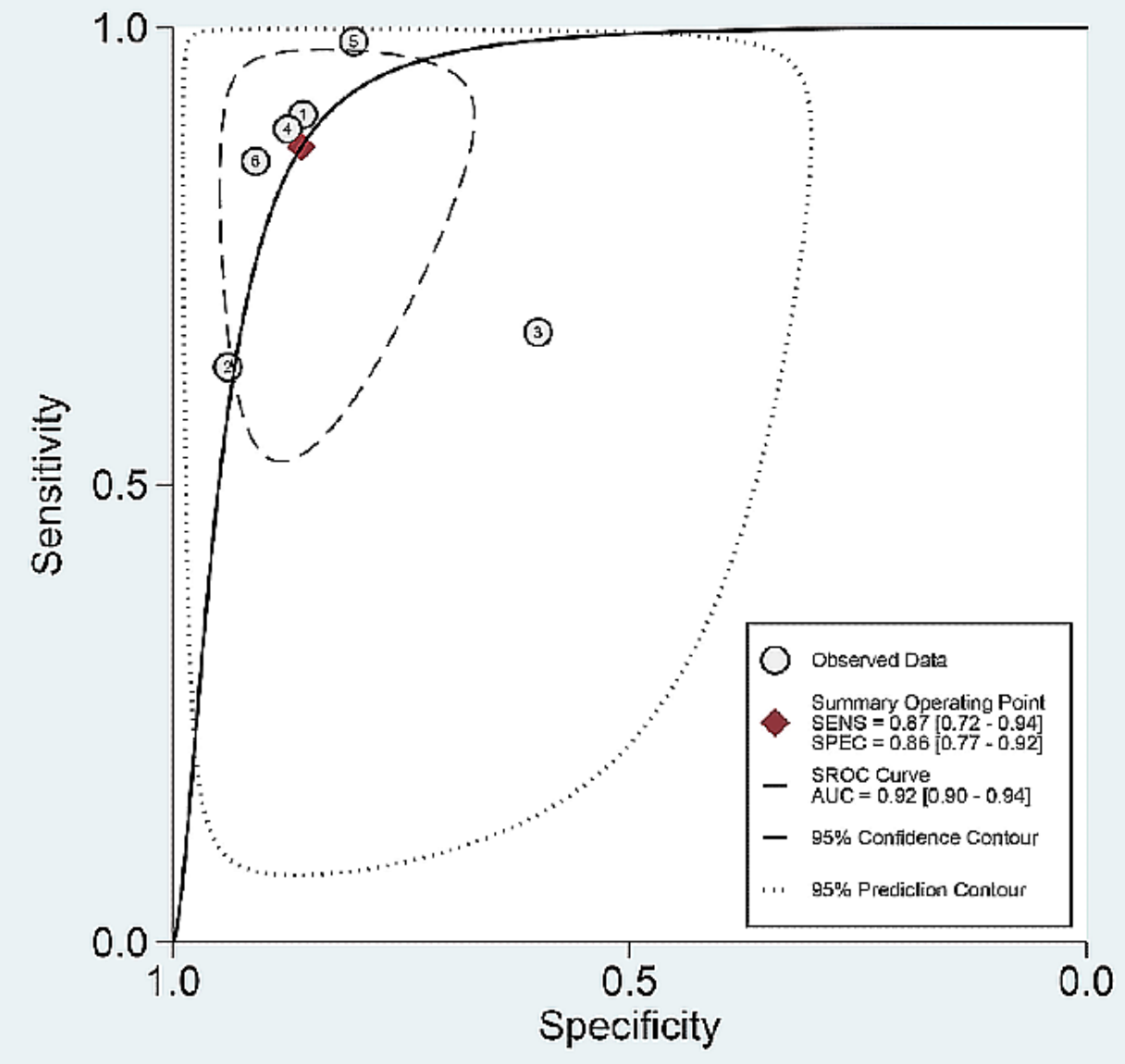


Figure 5. Fagan normogram for the prediction of Helicobacter pylori infection in endoscopic images.
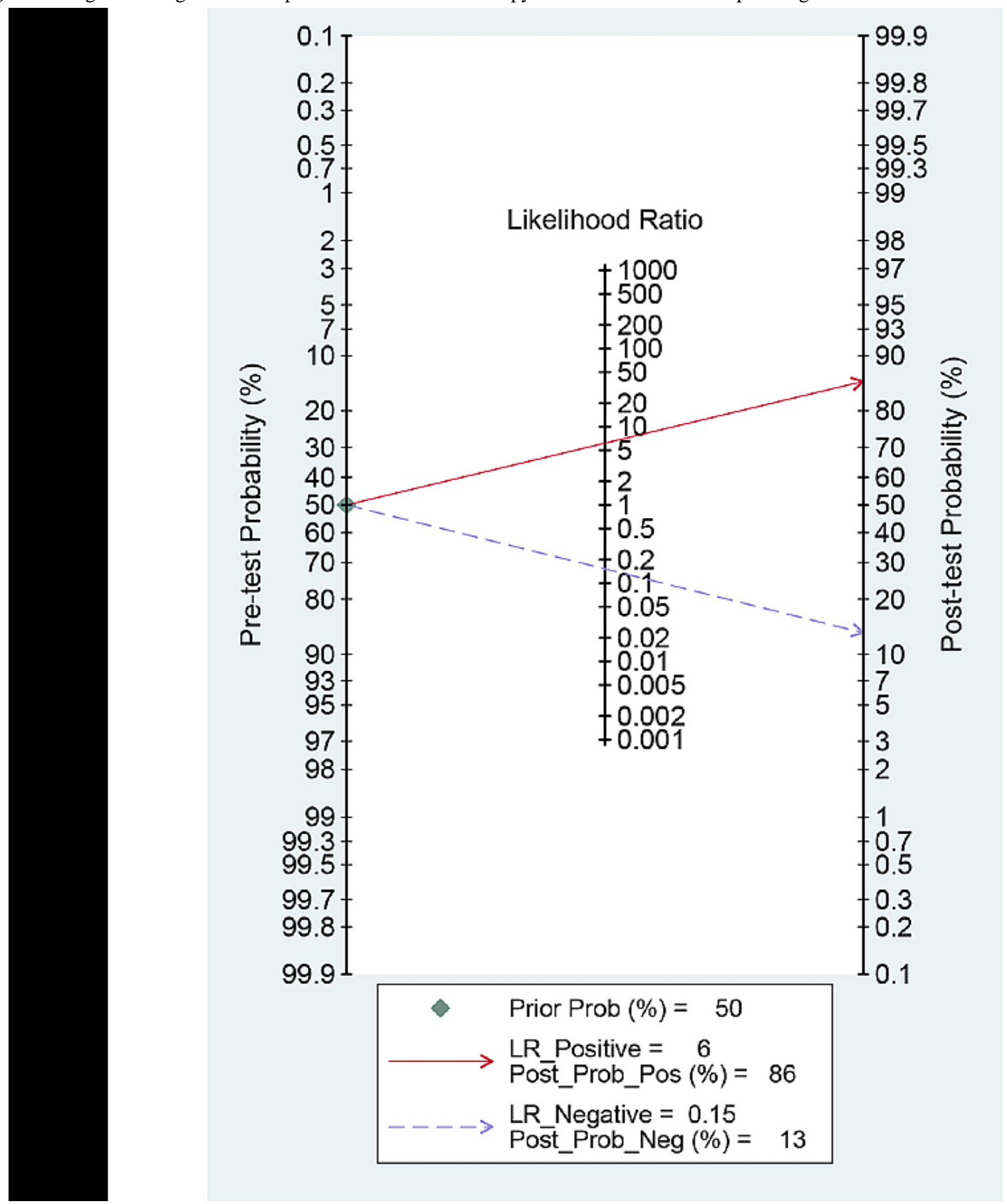

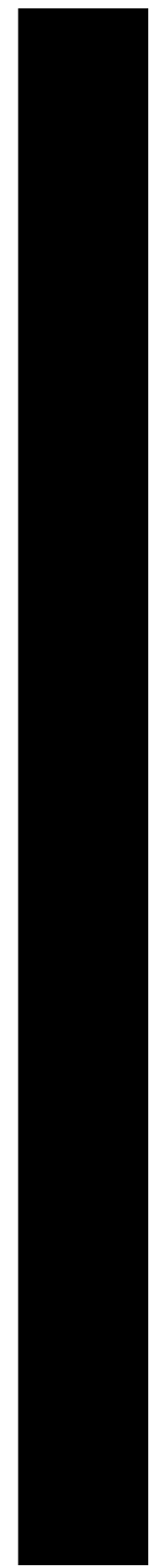

Among the 4 studies [9,10,21,24] of image-based analysis, sensitivity, specificity, PLR, NLR, DOR, and AUC with 95\% CI of AI for the prediction of H pylori infection were $0.81(95 \%$ CI 0.68-0.90), 0.93 (95\% CI 0.82-0.98), 12.3 (95\% CI 3.8-39.2), 0.20 (95\% CI $0.11-0.38), 61$ (95\% CI 11-322), and 0.93 (95\% CI 0.90-0.95), respectively (Table 3).

Only 2 studies $[9,10]$ reported outcomes related to discrimination between noninfected images and posteradication images. Therefore, a meta-analysis was not possible. Pooled analysis of the crude value of TP, FP, FN, and TN revealed that accuracy of the AI algorithm reached $82.01 \%(857 / 1045)$.

Additionally, only 2 studies $[9,10]$ reported outcomes regarding discrimination between images showing $H$ pylori infection and posteradication images. Therefore, a meta-analysis was not possible. However, pooled analysis of the crude value of TP,
$\mathrm{FP}, \mathrm{FN}$, and $\mathrm{TN}$ revealed that accuracy of the AI algorithm reached $77.0 \%(521 / 677)$.

Regarding comparison of the performance between AI and endoscopists, only 2 studies presented outcomes [10,22]. In the study by Yasuda et al [10], the diagnostic accuracy of an SVM-based AI algorithm was superior to that of inexperienced endoscopists. However, there was no significant difference between experienced endoscopists and the AI algorithm [10]. The accuracy of a CNN-based AI algorithm reached $87.7 \%$ in the study by Shichijo et al [22], while the accuracy achieved by endoscopists was $82.4 \%$. The difference was statistically significant between the AI algorithm and endoscopists (5.3\%, 95\% CI 0.3-10.2) [22]. 


\section{Exploring Heterogeneity With Meta-Regression and Subgroup Analysis}

For the prediction of $H$ pylori infection using endoscopic images, the SROC curve was generated in the patient-based studies. The shape of the curve was symmetric (Figure 4). We observed a negative correlation coefficient between logit transformed sensitivity and specificity $(-0.22)$ and an asymmetric parameter, $\beta$, with a nonsignificant $P$ value $(P=.29)$ indicating no heterogeneity among the studies. However, the $95 \%$ prediction region in the SROC curve was wide, and the methodological quality among the included studies $(P<.001)$ and total number of included patients $(P=.03)$ were found to be the source of heterogeneity in the joint model of meta-regression (published year $[P=.41]$, study format $[P=.10]$, type of endoscopic image $[P=.92]$, and type of AI [P=.07]; Figure 6). Subgroup analyses, based on the modifiers of heterogeneity, showed higher AUCs or DORs in studies with a large population of patients $(\leq 100)$ or those demonstrating high methodological quality (Table 2).

In terms of the image-based analysis, the overall number of included studies was 4, and subgroup analysis was possible with only 3 studies. Studies with CNN (vs SVM) and studies with
WLI (vs LCI) showed higher AUCs or DORs (Table 3). However, these modifiers (type of AI and type of endoscopic imaging) were not a significant covariate in the meta-regression analysis (total number of included patients $[P=.06]$, methodological quality $[P=.68]$, published year $[P=.78]$, study format $[P=.68]$, type of endoscopic image $[P=.72]$, or type of AI $[P=.72])$.

The enrolled studies included various types of control groups. The fundamental question of this study was whether the AI algorithm could differentiate endoscopic images between an $H$ pylori-positive and a naïve gastric mucosa. Table 1 shows the types of control group included in each study. Two studies clearly presented the classifying performance of an AI algorithm discriminating $H$ pylori-positive and $H$ pylori-naïve in a patient-based analysis, and there were 3 with image-based analysis. Subgroup analysis was also performed and showed slightly lower AUCs or DORs in patient-based or image-based analysis (Table 2 and 3). However, this factor (studies with clearly presented classifying performance data discriminating $H$ pylori-positive and $H$ pylori-naïve group) was not a significant modifier in the meta-regression analysis $(P=.21$ in the patient-based analysis, and $P=.10$ in the image-based analysis). 
Figure 6. Meta-regression for the reason of heterogeneity in the diagnostic test accuracy meta-analysis. nopt: number of patients.

\section{Univariable Meta-regression \& Subgroup Analyses}
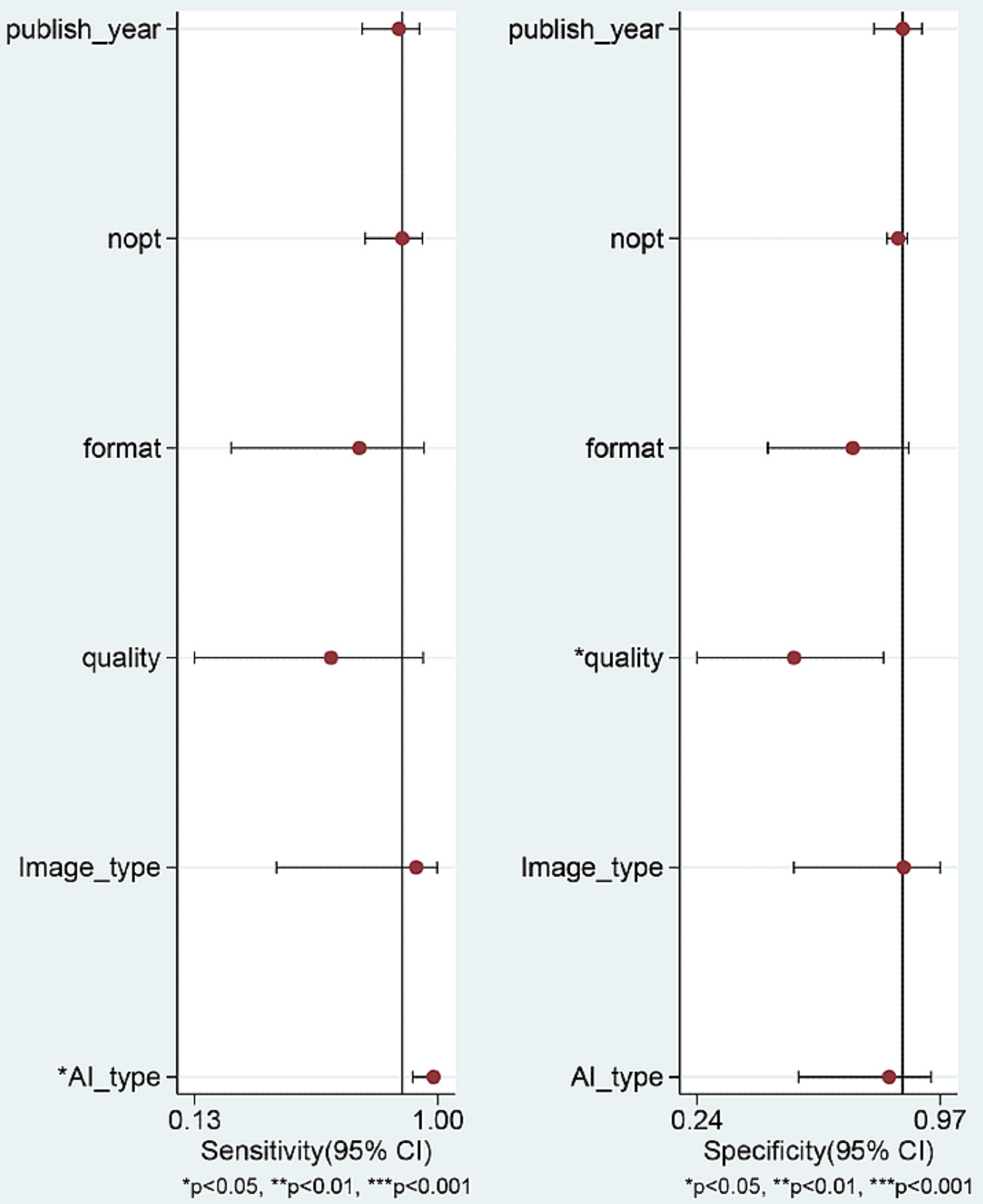
Table 3. Summary of diagnostic test accuracy and subgroup analysis of the included studies with image-based analysis.

\begin{tabular}{|c|c|c|c|c|c|c|c|}
\hline Subgroup & $\begin{array}{l}\text { Number } \\
\text { of in- } \\
\text { cluded } \\
\text { studies }\end{array}$ & $\begin{array}{l}\text { Sensitivity (95\% } \\
\mathrm{CI})\end{array}$ & $\begin{array}{l}\text { Specificity }(95 \% \\
\text { CI) }\end{array}$ & $\mathrm{PLR}^{\mathrm{a}}$ & $\mathrm{NLR}^{\mathrm{b}}$ & $\mathrm{DOR}^{\mathrm{c}}$ & $\mathrm{AUC}^{\mathrm{d}}$ \\
\hline $\begin{array}{l}\text { Value of meta-analy- } \\
\text { sis in all the included } \\
\text { (bivariate and }\end{array}$ & 4 & $0.81(0.68-0.90)$ & $0.93(0.82-0.98)$ & $12.3(3.8-39.2)$ & $0.20(0.11-0.38)$ & $61(11-322)$ & $0.93(0.90-0.95)$ \\
\hline $\begin{array}{l}\text { Value of meta-analy- } \\
\text { sis in all the included } \\
\text { (Moses-Shapiro-Lit- } \\
\text { tenberg method) }\end{array}$ & & $0.90(0.89-0.91)$ & $0.94(0.93-0.95)$ & $11.1(1.6-76.2)$ & $0.20(0.08-0.52)$ & $56(5-591)$ & $0.90(0.71-0.99)$ \\
\hline \multicolumn{8}{|l|}{$\begin{array}{l}\text { Methodological } \\
\text { quality of included } \\
\text { studies }\end{array}$} \\
\hline High quality & 3 & $0.90(0.87-0.91)$ & $0.94(0.93-0.95)$ & $13.1(1.4-124.5)$ & $0.22(0.08-0.62)$ & $61(4-919)$ & $0.87(0.43-0.99)$ \\
\hline Low quality & 1 & Null & Null & Null & Null & Null & Null \\
\hline \multicolumn{8}{|l|}{$\begin{array}{l}\text { Total number of in- } \\
\text { cluded patients }\end{array}$} \\
\hline$\leq 100$ & 3 & $0.90(0.87-0.91)$ & $0.94(0.93-0.95)$ & $13.1(1.4-124.5)$ & $0.22(0.08-0.62)$ & $61(4-919)$ & $0.87(0.43-0.99)$ \\
\hline$<100$ & 1 & Null & Null & Null & Null & Null & Null \\
\hline \multicolumn{8}{|l|}{ Format of study } \\
\hline Retrospective & 3 & $0.90(0.87-0.91)$ & $0.94(0.93-0.95)$ & $13.1(1.4-124.5)$ & $0.22(0.08-0.62)$ & $61(4-919)$ & $0.87(0.43-0.99)$ \\
\hline Prospective & 1 & Null & Null & Null & Null & Null & Null \\
\hline \multicolumn{8}{|l|}{ Published year } \\
\hline Before 2010 & 0 & & & & & & \\
\hline \multicolumn{8}{|l|}{ Type of AI $\mathbf{I}^{\mathbf{f}}$} \\
\hline $\begin{array}{l}\text { Neural net- } \\
\text { work-based }\end{array}$ & 3 & $0.91(0.90-0.92)$ & $0.97(0.96-0.97)$ & $16.8(2.0-141.7)$ & $0.17(0.05-0.61)$ & $98(6-1640)$ & $0.95(0.75-0.99)$ \\
\hline SVM $^{\mathrm{g}}$-based & 1 & Null & Null & Null & Null & Null & Null \\
\hline \multicolumn{8}{|l|}{$\begin{array}{l}\text { Type of endoscopic } \\
\text { image }\end{array}$} \\
\hline $\mathrm{WLI}^{\mathrm{h}}$ & 3 & $0.91(0.90-0.92)$ & $0.97(0.96-0.97)$ & $16.8(2.0-141.7)$ & $0.17(0.05-0.61)$ & $98(6-1640)$ & $0.95(0.75-0.99)$ \\
\hline $\mathrm{LCI}^{\mathrm{i}}$ & 1 & Null & Null & Null & Null & Null & Null \\
\hline $\begin{array}{l}\text { Classifying perfor- } \\
\text { mance between Heli- } \\
\text { cobacter pylori-posi- } \\
\text { tive vs } H \text { pylori-naïve } \\
\text { images }\end{array}$ & 3 & $0.77(0.71-0.82)$ & $0.96(0.94-0.98)$ & $11.8(3.7-38.3)$ & $0.26(0.21-0.32)$ & $53(17-161)$ & $0.88(0.79-0.96)$ \\
\hline
\end{tabular}

apR: positive likelihood ratio.

${ }^{\mathrm{b}} \mathrm{NLR}$ : negative likelihood ratio.

${ }^{\mathrm{c}}$ DOR: diagnostic odds ratio.

${ }^{\mathrm{d}} \mathrm{AUC}$ : area under the curve.

${ }^{\mathrm{e}}$ HSROC: hierarchical summary receiver operating characteristic.

${ }^{\mathrm{f}} \mathrm{AI}$ : artificial intelligence.

${ }^{\text {g }}$ SM: support vector machine.

${ }^{\mathrm{h}}$ WLI: white-light imaging.

${ }^{\mathrm{i}} \mathrm{LCI}$ : linked color imaging. 


\section{Publication Bias}

Figure 7 shows the Deek funnel plot of studies of patient-based analysis and Figure 8 shows the Deek funnel plot of studies of

Figure 7. Deek funnel plot for the studies of patient-based analysis. image-based analysis. The plot was grossly symmetrical with respect to the regression line. The Deek funnel plot asymmetry test showed no evidence of publication bias $(P=.38$ in the patient-based analysis, and $P=.27$ in the image-based analysis).

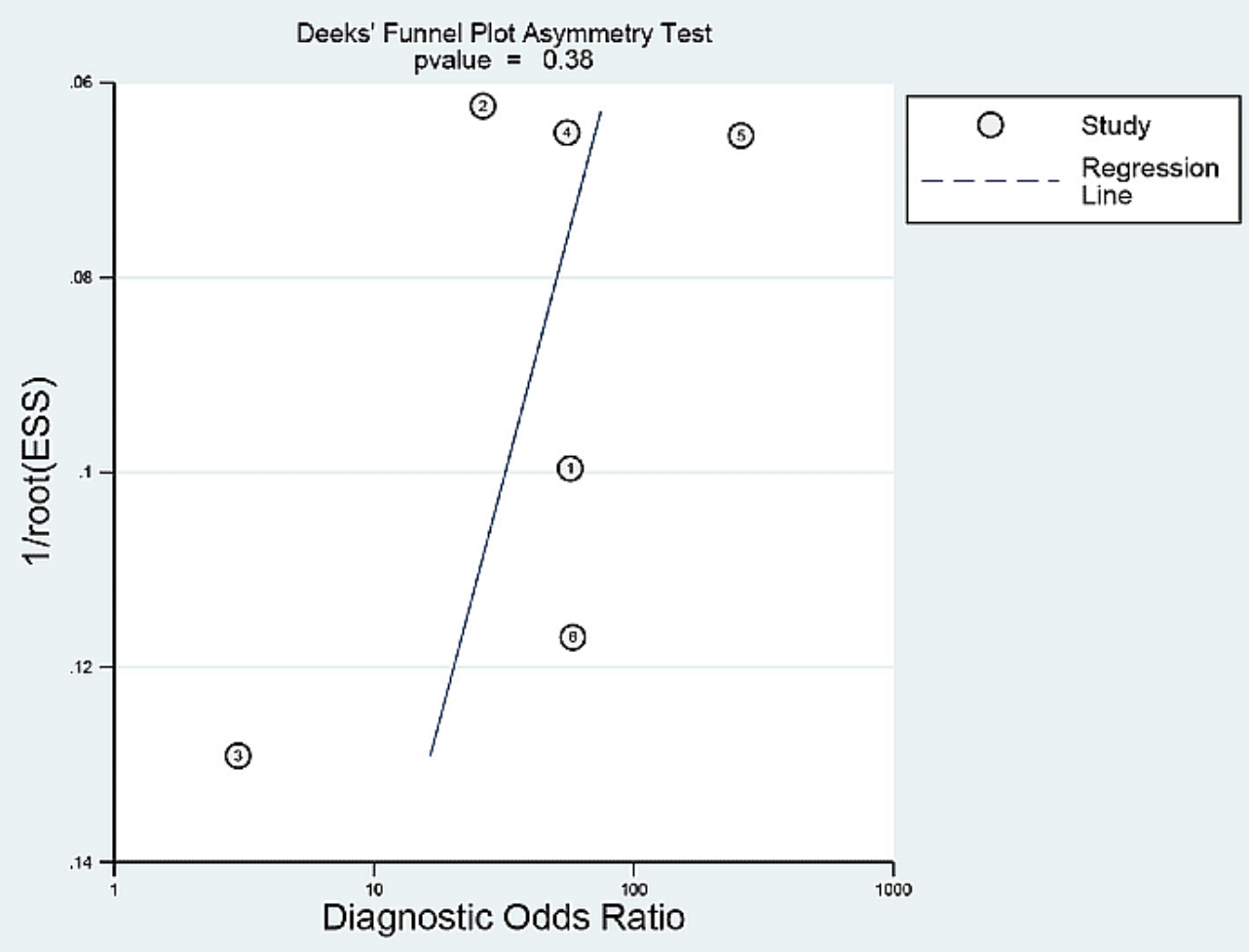

Figure 8. Deek funnel plot for the studies of image-based analysis.

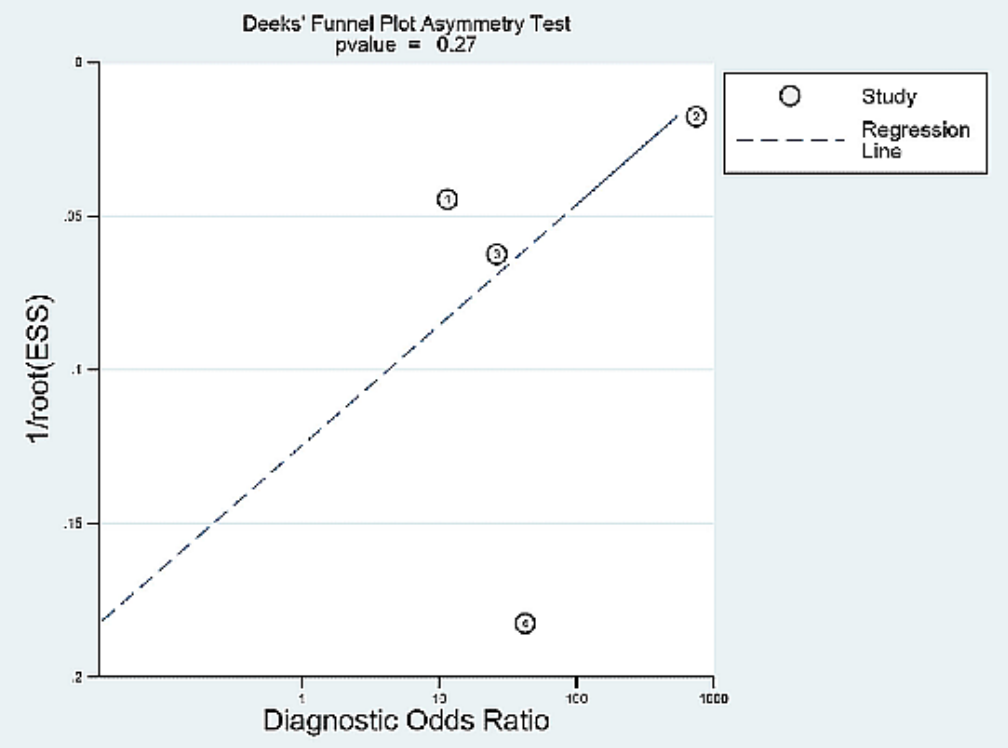




\section{Discussion}

\section{Principal Findings}

This study presented the good performance of the AI algorithm applied to endoscopic diagnosis of $H$ pylori infection, indicating that AI-assisted endoscopy is feasible in clinical practice. Indeed, this approach might be characterized as a computer-aided diagnosis, and the most important benefit consists of the improvement in diagnostic accuracy of conventional endoscopy with WLI [28]. Optical endoscopic diagnosis has operator-dependent characteristics, and the diagnostic process is completely subjective. However, AI-assisted endoscopy could be helpful in providing a second opinion and may help avoid operator dependency in diagnostic endoscopy [28]. Currently, it is unclear how endoscopists would react to a diagnosis made using $\mathrm{AI}$ (examples from the literature include approval, a learning opportunity, or "presenting an indolent attitude") [28,29]. Therefore, a prospective study based on the application of $\mathrm{AI}$ in clinical practice (more specifically, in diagnostic endoscopy) is essential [30,31]. However, providing robust answers using an AI algorithm irrespective of the endoscopists' inspection would be helpful to increase the likelihood of identifying important findings in diagnostic endoscopy. As endoscopic biopsy is an invasive procedure, application of a highly accurate AI algorithm in endoscopic examination may reduce the need for unnecessary biopsies in a substantial proportion of patients.

Another important finding of this study is the robustness of the diagnostic performance of the AI algorithm, irrespective of the modifiers detected during the systematic review process. Although studies based on a large population of patients presenting high methodological quality demonstrated higher diagnostic performance, this difference in diagnostic performance was not substantial. Neither the type of AI, such as CNN or SVM, nor the type of endoscopic images used, such as WLI, LCI, or BLI, affected overall diagnostic performance. Studies with patient-based analysis and image-based analysis commonly presented a good performance of AI for the diagnosis of $H$ pylori infection (Tables 2 and 3 ).

$\mathrm{AI}$ is generally characterized as being of a black-box nature due to the difficulty in explaining the determination of the AI algorithm. The class activation map is a technique for visualizing the locations to which established AI algorithms pay attention and indicating a region of interest. This technique offers the possibility of explaining the determination of the AI algorithm. Although only one study [23] included in this systematic review adopted this type of feature map with the AI algorithm, this technique has now been widely adopted for the establishment of the AI algorithm and could be useful for the work of endoscopists, specifically for targeted biopsy in $H$ pylori detection.

In terms of the IEE, the ultimate goal of this technique would be optical biopsy replacing invasive histologic examination with the aid of discrete differentiation and enhancement of surface mucosal features. Previous studies on the diagnosis of $H$ pylori infection with WLI showed low sensitivity and poor interobserver agreement [11,32-34]. However, studies with IEE commonly showed increased diagnostic accuracy of premalignant or malignant lesions during endoscopic examination $[11,12]$. Previous studies with IEE also indicated the usefulness of LCI for the diagnosis of $H$ pylori infection $[35,36]$. Although a recently published systematic review concluded that currently no established uniform findings exist for optical endoscopic diagnosis of $H$ pylori infection [8], IEE continues to have potential for the differentiation of $H$ pylori infection. The development of standardized validated indicators is required. The additive effect of magnifying endoscopy in NBI also showed promising results for the diagnosis of $H$ pylori infection [37,38]. Due to insufficient data on IEE for the application of AI in this study, the real value of IEE with AI could not be evaluated. Further studies using various types of IEE with AI applications is essential.

\section{Limitations}

Although, this review rigorously investigated the diagnostic accuracy of the AI algorithm for $H$ pylori infection in endoscopic images, our analysis has several inevitable limitations originating from potential bias in each study. First, the diagnostic performance of AI could have been exaggerated. It is more likely that the endoscopic images in each included study may have distinct features of $H$ pylori infection and a clear and focused view, leading to a selection bias [28]. Second, the overfitting (modeling error that occurs when a certain learning model is excessively tailored to the training dataset and predictions are not well generalized to new datasets) of the AI algorithm cannot be excluded [31]. The diagnostic performance of the AI algorithms can only be valid for the population under evaluation and depends on the prevalence of target conditions for the selected population (so-called spectrum bias or class imbalance). The best and only way to prove the real performance of an AI algorithm is external (prospective) validation using unused datasets for model development, collected in a way that minimizes the spectrum bias [31]. However, there is no single study that adopted external validation for the performance of an established AI algorithm in this systematic review. Moreover, all the enrolled studies were conducted at a single center, which limits the generalization of the results. Third, there were little data regarding posteradication images, thus increasing the difficulty of the analysis of performance in the discrimination of uninfected and posteradicated images of $H$ pylori infection. In real clinical practice, patients are not divided into only 2 categories of infected or noninfected patients. Indeed, there are many posteradicated patients, and this aspect should be reflected in the establishment of an AI algorithm. However, only 2 studies considered this category and conducted a separate analysis $[9,10]$. Because there were only 4 studies that conducted multiple tests in enrolling $H$ pylori-infected patients, there may be a concern for selection bias. However, this factor is not expected to affect the overall results because there is a high probability of actual infection if any type of test is positive. Moreover, this factor was reflected in the methodological quality, and authors verified the effect of this bias through additional meta-regression. All the included studies were conducted in Asia, and no study confirmed the diagnostic validity of AI using external validation. Since the age of the 
enrolled population ranged from a mean of 48.6 years to a median of 64 years, excluding a younger population, further studies are required to understand the real value of the widespread use of this algorithm. Considering the high accuracy and real-time diagnostic characteristics, the results of this study indicate the clinical utility of using an AI algorithm as an additive tool for the prediction of $H$ pylori infection during endoscopic procedures. It is highly likely that AI could replace endoscopists' diagnoses of $H$ pylori infections as guessed by visual inspection based on the evidence of this study. The real potential would be elucidated through the clinical application studies.

\section{Conclusion}

In conclusion, an $\mathrm{AI}$ algorithm can be considered a reliable tool for endoscopic diagnosis of $H$ pylori infection. The limitations of lacking external validation performance and being conducted only in Asia should be overcome.

\section{Acknowledgments}

Funding for this research was provided by the Bio \& Medical Technology Development Program of the National Research Foundation and the Korean government, Ministry of Science and ICT (grant number NRF2017M3A9E8033253).

\section{Authors' Contributions}

CSB was responsible for conceptualization, data curation, formal analysis, funding acquisition, investigation, methodology, project administration, resources, supervision, writing the original draft, and reviewing and editing the final draft. JJL was responsible for data curation, formal analysis, investigation, and resources. GHB was responsible for data curation, formal analysis, investigation, and resources.

\section{Conflicts of Interest}

None declared.

\section{Multimedia Appendix 1}

Search strategy used to find relevant articles.

[DOCX File, $20 \mathrm{~KB}$-Multimedia Appendix 1]

\section{Multimedia Appendix 2}

Data extraction, primary- and modifier-based analyses, and statistical analysis.

[DOCX File, 23 KB-Multimedia Appendix 2]

\section{References}

1. Hooi JKY, Lai WY, Ng WK, Suen MMY, Underwood FE, Tanyingoh D, et al. Global prevalence of Helicobacter pylori infection: systematic review and meta-analysis. Gastroenterology 2017 Aug;153(2):420-429 [FREE Full text] [doi: 10.1053/j.gastro.2017.04.022] [Medline: 28456631]

2. Chey WD, Leontiadis GI, Howden CW, Moss SF. ACG clinical guideline: treatment of Helicobacter pylori infection. Am J Gastroenterol 2017 Feb;112(2):212-239. [doi: 10.1038/ajg.2016.563] [Medline: 28071659]

3. Bang CS, Lee JJ, Baik GH. The most influential articles in Helicobacter pylori research: a bibliometric analysis. Helicobacter 2019 Aug;24(4):e12589. [doi: 10.1111/hel.12589] [Medline: 31033071]

4. Correa P. A human model of gastric carcinogenesis. Cancer Res 1988 Jul 01;48(13):3554-3560 [FREE Full text] [Medline: 3288329]

5. IARC monographs on the evaluation of carcinogenic risks to humans. In: International Agency for Research on Cancer, ed Shistosomes, Liver Flukes and Helicobacter pylori. Vol. 61. Lyon: International Agency for Research on Cancer; 1994.

6. IARC working group reports. In: International Agency for Research on Cancer, ed Helicobacter pylori Eradication as a Strategy for Preventing Gastric Cancer. Vol. 8. Lyon: International Agency for Research on Cancer; 2014.

7. Bang CS, Baik GH, Shin IS, Kim JB, Suk KT, Yoon JH, et al. Helicobacter pylori eradication for prevention of metachronous recurrence after endoscopic resection of early gastric cancer. J Korean Med Sci 2015 Jun;30(6):749-756 [FREE Full text] [doi: 10.3346/jkms.2015.30.6.749] [Medline: 26028928]

8. Glover B, Teare J, Patel N. A systematic review of the role of non-magnified endoscopy for the assessment of infection. Endosc Int Open 2020 Feb;8(2):E105-E114 [FREE Full text] [doi: 10.1055/a-0999-5252] [Medline: $\underline{\text { 32010741] }}$

9. Shichijo S, Endo Y, Aoyama K, Takeuchi Y, Ozawa T, Takiyama H, et al. Application of convolutional neural networks for evaluating Helicobacter pylori infection status on the basis of endoscopic images. Scand J Gastroenterol 2019 Feb;54(2):158-163. [doi: 10.1080/00365521.2019.1577486] [Medline: $\underline{\text { 30879352] }}$

10. Yasuda T, Hiroyasu T, Hiwa S, Okada Y, Hayashi S, Nakahata Y, et al. Potential of automatic diagnosis system with linked color imaging for diagnosis of Helicobacter pylori infection. Dig Endosc 2020 Mar;32(3):373-381. [doi: 10.1111/den.13509] [Medline: $\underline{31398276]}$ 
11. Dohi O, Majima A, Naito Y, Yoshida T, Ishida T, Azuma Y, et al. Can image-enhanced endoscopy improve the diagnosis of Kyoto classification of gastritis in the clinical setting? Dig Endosc 2020 Jan;32(2):191-203. [doi: 10.1111/den.13540] [Medline: $\underline{31550395]}$

12. Kim J. Usefulness of narrow-band imaging in endoscopic submucosal dissection of the stomach. Clin Endosc 2018 Oct;51(6):527-533 [FREE Full text] [doi: 10.5946/ce.2018.186] [Medline: 30453446]

13. Cho B, Bang CS. Artificial intelligence for the determination of a management strategy for diminutive colorectal polyps: hype, hope, or help. Am J Gastroenterol 2020 Jan;115(1):70-72. [doi: 10.14309/ajg.0000000000000476] [Medline: 31770118]

14. Cho B, Bang CS, Park SW, Yang YJ, Seo SI, Lim H, et al. Automated classification of gastric neoplasms in endoscopic images using a convolutional neural network. Endoscopy 2019 Dec;51(12):1121-1129. [doi: 10.1055/a-0981-6133] [Medline: 31443108]

15. McInnes MDF, Moher D, Thombs BD, McGrath TA, Bossuyt PM, PRISMA-DTA Group, et al. Preferred reporting items for a systematic review and meta-analysis of diagnostic test accuracy studies: the PRISMA-DTA statement. JAMA 2018 Jan 23;319(4):388-396. [doi: 10.1001/jama.2017.19163] [Medline: 29362800]

16. Whiting PF, Rutjes AWS, Westwood ME, Mallett S, Deeks JJ, Reitsma JB, QUADAS-2. QUADAS-2: a revised tool for the quality assessment of diagnostic accuracy studies. Ann Intern Med 2011 Oct 18;155(8):529-536. [doi: 10.7326/0003-4819-155-8-201110180-00009] [Medline: 22007046]

17. Bang CS, Lee JJ, Baik GH. Prediction of chronic atrophic gastritis and gastric neoplasms by serum pepsinogen assay: a systematic review and meta-analysis of diagnostic test accuracy. J Clin Med 2019 May 10;8(5):657 [FREE Full text] [doi: 10.3390/jcm8050657] [Medline: 31083485]

18. Reitsma JB, Glas AS, Rutjes AWS, Scholten RJPM, Bossuyt PM, Zwinderman AH. Bivariate analysis of sensitivity and specificity produces informative summary measures in diagnostic reviews. J Clin Epidemiol 2005 Oct;58(10):982-990. [doi: 10.1016/j.jclinepi.2005.02.022] [Medline: 16168343]

19. Rutter CM, Gatsonis CA. A hierarchical regression approach to meta-analysis of diagnostic test accuracy evaluations. Stat Med 2001 Oct 15;20(19):2865-2884. [doi: 10.1002/sim.942] [Medline: 11568945]

20. Harbord RM, Whiting P. Metandi: meta-analysis of diagnostic accuracy using hierarchical logistic regression. The Stata Journal 2018 Nov 19;9(2):211-229. [doi: 10.1177/1536867x0900900203]

21. Zheng W, Zhang X, Kim JJ, Zhu X, Ye G, Ye B, et al. High accuracy of convolutional neural network for evaluation of Helicobacter pylori infection based on endoscopic images: preliminary experience. Clin Transl Gastroenterol 2019 Dec;10(12):e00109 [FREE Full text] [doi: 10.14309/ctg.0000000000000109] [Medline: 31833862]

22. Shichijo S, Nomura S, Aoyama K, Nishikawa Y, Miura M, Shinagawa T, et al. Application of convolutional neural networks in the diagnosis of Helicobacter pylori infection based on endoscopic images. EBioMedicine 2017 Nov;25:106-111 [FREE Full text] [doi: 10.1016/j.ebiom.2017.10.014] [Medline: 29056541]

23. Nakashima H, Kawahira H, Kawachi H, Sakaki N. Artificial intelligence diagnosis of infection using blue laser imaging-bright and linked color imaging: a single-center prospective study. Ann Gastroenterol 2018;31(4):462-468 [FREE Full text] [doi: 10.20524/aog.2018.0269] [Medline: 29991891]

24. Itoh T, Kawahira H, Nakashima H, Yata N. Deep learning analyzes Helicobacter pylori infection by upper gastrointestinal endoscopy images. Endosc Int Open 2018 Feb;6(2):E139-E144 [FREE Full text] [doi: 10.1055/s-0043-120830] [Medline: 29399610]

25. Huang C, Chung P, Sheu B, Kuo H, Popper M. Helicobacter pylori-related gastric histology classification using support-vector-machine-based feature selection. IEEE Trans Inf Technol Biomed 2008 Jul;12(4):523-531. [doi: 10.1109/TITB.2007.913128] [Medline: 18632332 ]

26. Huang C, Sheu B, Chung P, Yang H. Computerized diagnosis of Helicobacter pylori infection and associated gastric inflammation from endoscopic images by refined feature selection using a neural network. Endoscopy 2004 Jul;36(7):601-608. [doi: $10.1055 / \mathrm{s}-2004-814519]$ [Medline: 15243882$]$

27. Best LM, Takwoingi Y, Siddique S, Selladurai A, Gandhi A, Low B, et al. Non-invasive diagnostic tests for Helicobacter pylori infection. Cochrane Database Syst Rev 2018 Mar 15;3:CD012080 [FREE Full text] [doi:

10.1002/14651858.CD012080.pub2] [Medline: 29543326]

28. Hoogenboom SA, Bagci U, Wallace MB. Artificial intelligence in gastroenterology. The current state of play and the potential. How will it affect our practice and when? Tech Innov Gastrointest Endosc 2020 Apr;22(2):42-47. [doi: 10.1016/j.tgie.2019.150634]

29. Abdullah R, Fakieh B. Health care employees' perceptions of the use of artificial intelligence applications: survey study. $\mathbf{J}$ Med Internet Res 2020 May 14;22(5):e17620 [FREE Full text] [doi: 10.2196/17620] [Medline: 32406857]

30. Tian Y, Liu X, Wang Z, Cao S, Liu Z, Ji Q, et al. Concordance between Watson for oncology and a multidisciplinary clinical decision-making team for gastric cancer and the prognostic implications: retrospective study. J Med Internet Res 2020 Feb 20;22(2):e14122 [FREE Full text] [doi: 10.2196/14122] [Medline: 32130123]

31. Yang YJ, Bang CS. Application of artificial intelligence in gastroenterology. World J Gastroenterol 2019 Apr 14;25(14):1666-1683 [FREE Full text] [doi: 10.3748/wjg.v25.i14.1666] [Medline: 31011253 ]

32. Bah A, Saraga E, Armstrong D, Vouillamoz D, Dorta G, Duroux P, et al. Endoscopic features of Helicobacter pylori-related gastritis. Endoscopy 1995 Oct;27(8):593-596. [doi: 10.1055/s-2007-1005764] [Medline: $\underline{8608753]}$ 
33. Laine L, Cohen H, Sloane R, Marin-Sorensen M, Weinstein WM. Interobserver agreement and predictive value of endoscopic findings for H. pylori and gastritis in normal volunteers. Gastrointest Endosc 1995 Nov;42(5):420-423. [doi: 10.1016/s0016-5107(95)70043-9] [Medline: $\underline{\text { 8566631] }}$

34. Redéen S, Petersson F, Jönsson K, Borch K. Relationship of gastroscopic features to histological findings in gastritis and Helicobacter pylori infection in a general population sample. Endoscopy 2003 Nov;35(11):946-950. [doi: 10.1055/s-2003-43479] [Medline: 14606018]

35. Dohi O, Yagi N, Onozawa Y, Kimura-Tsuchiya R, Majima A, Kitaichi T, et al. Linked color imaging improves endoscopic diagnosis of active Helicobacter pylori infection. Endosc Int Open 2016 Jul;4(7):E800-E805 [FREE Full text] [doi: 10.1055/s-0042-109049] [Medline: 27556101]

36. Takeda T, Asaoka D, Nojiri S, Nishiyama M, Ikeda A, Yatagai N, et al. Linked color imaging and the Kyoto classification of gastritis: evaluation of visibility and inter-rater reliability. Digestion 2019 Jul 12:1-10. [doi: 10.1159/000501534] [Medline: $\underline{31302654]}$

37. Yagi K, Saka A, Nozawa Y, Nakamura A. Prediction of Helicobacter pylori status by conventional endoscopy, narrow-band imaging magnifying endoscopy in stomach after endoscopic resection of gastric cancer. Helicobacter 2014 Apr;19(2):111-115. [doi: 10.1111/hel.12104] [Medline: 24372729]

38. Kanzaki H, Uedo N, Ishihara R, Nagai K, Matsui F, Ohta T, et al. Comprehensive investigation of areae gastricae pattern in gastric corpus using magnifying narrow band imaging endoscopy in patients with chronic atrophic fundic gastritis. Helicobacter 2012 Jun;17(3):224-231 [FREE Full text] [doi: 10.1111/j.1523-5378.2012.00938.x] [Medline: 22515361]

\section{Abbreviations}

AI: artificial intelligence

AUC: area under the curve

BLI: blue-laser imaging

CNN: convolutional neural network

DOR: diagnostic odds ratio

FN: false negative

FP: false positive

IEE: image-enhanced endoscopy

LCI: linked color imaging

NBI: narrow-band imaging

NLR: negative likelihood ratio

NPV: negative predictive value

PLR: positive likelihood ratio

PRISMA-DTA: Preferred Reporting Items for a Systematic Review and Meta-analysis of Diagnostic Test Accuracy Studies

PROSPERO: International Prospective Register of Systematic Reviews

PPV: positive predicted value

QUADAS-2: Quality Assessment of Diagnostic Accuracy Studies-2

SROC: summary receiver operating characteristic

SVM: support vector machine

TN: true negative

TP: true positive

WLI: white-light imaging

Edited by G Eysenbach; submitted 30.06.20; peer-reviewed by J Chung, J Frausto-Solis; comments to author $31.07 .20 ;$ revised version
received $02.08 .20 ;$ accepted 03.08.20; published 16.09 .20
Please cite as:
Bang CS, Lee JJ, Baik GH
Artificial Intelligence for the Prediction of Helicobacter Pylori Infection in Endoscopic Images: Systematic Review and Meta-Analysis
Of Diagnostic Test Accuracy
J Med Internet Res 2020;22(9):e21983
URL: $\underline{\text { http://www.jmir.org/2020/9/e21983/ }}$
doi: $\underline{10.2196 / 21983}$
PMID: $\underline{32936088}$


(C) Chang Seok Bang, Jae Jun Lee, Gwang Ho Baik. Originally published in the Journal of Medical Internet Research (http://www.jmir.org), 16.09.2020. This is an open-access article distributed under the terms of the Creative Commons Attribution License (https://creativecommons.org/licenses/by/4.0/), which permits unrestricted use, distribution, and reproduction in any medium, provided the original work, first published in the Journal of Medical Internet Research, is properly cited. The complete bibliographic information, a link to the original publication on http://www.jmir.org/, as well as this copyright and license information must be included. 